\title{
HUDUDTERHADAP PENCURIAN DAN PENODONGAN ATAU PERAMPOKAN DIBANDINGKAN DENGAN KETENTUAN HUKUM PIDANA POSITIF INDONESIA
}

\author{
Duwi Handoko \\ Sekolah Tinggi IImu Hukum (STIH) Persada Bunda | \\ Jalan Diponegoro Nomor 42 Kota Pekanbaru, 28 | |6 | \\ sepihak@gmail.com
}

\begin{abstract}
Allah exaggerated the threat of punishment for the perpetrators of the hijab above the threat of punishment for the perpetrators of murder or theft. This threat applies not only if the acts of hirabah are committed to Muslims, but also if they are carried out to other religious people who live under Islamic rule. Allah has mentioned the forms of punishment for the perpetrators of hirabah crimes, namely being killed (if they are only human lives without robbery), killed by crucifixion (if killing and seizing the victim's property), crossing their arms and legs crossed (those who only seizing property and not killing the victim), disposed of (if only the perpetrator commits terror or scares the victim by threatening). The threat of punishment for violent theft according to Article 365 of the Criminal Code is: Article 365 paragraph (I) of the Criminal Code (imprisonment for a maximum of nine years), Article 365 paragraph (2) of the Criminal Code (imprisonment for a maximum of twelve years), Article 365 paragraph (3) of the Criminal Code (jail sentence of fifteen years at the most). Article 365 paragraph (4) of the Criminal Code (capital punishment or life imprisonment or for a certain period of twenty years at the most).

Key Words: Muslims, Robbery, Theft
\end{abstract}

\begin{abstract}
Abstrak: Allah SWT melebihkan ancaman hukuman bagi pelaku hirabah di atas ancaman hukuman pelaku pembunuhan atau pencurian. Ancaman ini berlaku bukan hanya bila tindak hirabah itu dilakukan kepada pemeluk agama Islam, tetapi juga bila dilakukan kepada pemeluk agama lainnya yang hidup di bawah pemerintahan Islam. Allah SWT telah menyebutkan bentuk-bentuk hukuman buat para pelaku tindak kriminal hirabah, yaitu dibunuh (bila mereka hanya penghilangkan nyawa manusia tanpa
\end{abstract}


merampas), dibunuh dengan Disalib (bila membunuh sekaligus merampas harta korban), potong tangan dan kaki secara bersilangan (mereka yang hanya merampas harta dan tidak sampai membunuh korbannya), dibuang (bila hanya pelakunya melakukan teror semata atau menakuti korbannya dengan mengancam). Ancaman hukuman untuk pencurian dengan kekerasan menurut Pasal 365 Kitab Undang-Undang Hukum Pidana adalah: Pasal 365 ayat (I) KUHP (pidana penjara paling lama sembilan tahun), Pasal 365 ayat (2) KUHP (pidana penjara paling lama dua belas tahun), Pasal 365 ayat (3) KUHP (pidana penjara paling lama lima belas tahun). Pasal 365 ayat (4) KUHP (pidana mati atau pidana penjara seumur hidup atau selama waktu tertentu paling lama dua puluh tahun).

Kata kunci: Pemeluk Agama Islam, Pencurian, Perampokan

\section{Pendahuluan}

Kekuasaan menjatuhkan azab dan memberikan pahala atas sebuah perbuatan, berada di tangan Allah Swt. Dalam hal ini, berlaku sebuah adagium yang didasarkan atas kitab suci al-qur'an dan Hadits Nabi saw. Adagium itu berbunyi: "memberikan pengampunan dan menurunkan siksa kepada siapapun adalah otoritas Allah". Dalam hal ini kendali atas keadaan sepenuhnya berada di tangan Allah Swt. Dalam konteks ini pula, sebuah pengertian baru haruslah dipertimbangkan: sampai di manakah peranan negara dalam menjatuhkan hukuman, sebagai salah satu bentuk siksaan. Dapatkah negara atas nama Allah memberikan hukuman sebagai bagian dari siksa di dunia? sudahkah manusia terbebas diri siksa neraka, jikalau ia telah menjalani hukuman negara? Kalau belum, berarti ada penggandaan (dubblereren) antara negara sebagai wakil Allah dan kekuasaan Allah sendiri untuk menetapkan hukuman. Bukankah justru hal ini bertentangan dengan hadits Nabi Saw: jangan berlakukan hukum hadd ketika permasalahan tidak jelas. ${ }^{1}$

Hudud adalah hukuman-hukuman tertentu yang diwajibkan atas orang yang melanggar larangan-larangan

\footnotetext{
' Abdurrahman Wahid, Islamku, Islam Anda, Islam Kita: Agama Masyarakat Negara Demokrasi, (Wahid Institute: Jakarta, 2006), 8.
} 
tertentu. ${ }^{2}$ Tindak pidana hudud ada tujuh, yaitu zina, qazaf (menuduh zina), meminum minuman keras (khamar), mencuri, alhirabah (merampok/mengganggu keamanan, murtad, dan al-bagyu (memberontak). ${ }^{3}$

Sehubungan dengan hal tersebut di atas, maka tulisan ini bermaksud memaparkan berbagai hal, khususnya mengenai pencurian dan penodongan atau perampokan beserta jarimah-nya sebagai bahan perbandingan hukum dengan hukum lainnya, khususnya antara hukum pidana Islam dan hukum pidana positif Indonesia. Selain itu, untuk menggambarkan perbedaan antara pencurian dan perampokan dan perbuatan yang bagaimana dikategorikan sebagai perbuatan mencuri, dengan judul, "Hudud terhadap Pencurian dan Penodongan atau Perampokan Dibandingkan dengan Ketentuan Hukum Pidana Positif Indonesia".

Berdasarkan latar belakang masalah di atas, maka yang menjadi rumusan masalah dalam penelitian ini, yaitu: Pertama, bagaimanakah perbandingan hudud antara ketentuan hukum Islam dan hukum pidana positif Indonesia terhadap pencurian atau perbuatan mengambil harta orang lain secara sembunyi-sembunyi di dalam tempat simpanan hak orang lain tersebut? Kedua, bagaimanakah perbandingan hudud antara ketentuan hukum Islam dan hukum pidana positif Indonesia terhadap penodongan atau perampokan?

\section{Metode Penelitian}

Jenis penelitian ini adalah penelitian hukum normatif yang khusus membahas tentang pencurian. Metode pengumpulan data yang dilakukan di dalam penelitian ini adalah dengan cara studi kepustakaan dengan melakukan kajian terhadap literatur-literatur yang terkait dengan objek penelitian ini. Sedangkan analisis data

\footnotetext{
2 Sulaiman Rasjid, Figh Islam, Sinar (Baru Algensindo: Bandung, 1994), 436.

3 Tim Tsalisah, Ensiklopedi Hukum Pidana Islam, PT Kharisma IImu. Diterjemahkan dari buku AtTasyri' al-jina'i al-Islamiy Muqaranan bil Qanunil Wad'iy, I 50.
} 
dalam penelitian ini dilakukan secara sistematis berdasarkan permasalahan penelitian yang diuraikan secara kualitatif.

\section{Pembahasan}

Dalam bahasa Arab, pencurian disebut dengan istilah sariqah ( سَرِقَة ), yang maknanya adalah mengambil sesuatu dari orang lain dengan diam-diam (tersembunyi). ${ }^{4}$ Pencurian, yaitu mengambil harta milik orang lain dengan cara sembunyi dari tempat simpanan dengan maksud untuk dimiliki. Ancaman hukuman pencurian adalah potong tangan, namun harus memenuhi syarat-syarat tertentu yaitu: pencurinya harus dewasa, berakal sehat, dan tidak terpaksa, harta itu milik orang lain, pencuri mengambil harta dari tempat simpanan yang semestinya, sesuai dengan macam harta yang dicuri, harta yang dicuri memenuhi minimal 1,62 gram, dan pencurian tidak terjadi karena daya paksa, misalnya orang yang kelaparan mencuri untuk menyelamatkan jiwanya. ${ }^{5}$ Seorang pencuri tidak akan mencuri jika ketika itu dia berada di dalam keimanan, yaitu iman yang sempurna. ${ }^{6}$

Mencuri adalah mengambii benda atau barang milik orang lain secara diam-diam untuk dimiliki. Menipu, yaitu mengambil hak orang lain secara licik sehingga orang lain menderita kerugian. Korupsi, yaitu mengambil hak orang lain, baik perorangan atau masyarakat, dengan menggunakan kewenangan atas jabatan atau kekuasaannya, sehingga merugikan orang lain terkait. Menyuap, yaitu memberikan sesuatu baik uang atau lainnya kepada orang lain, agar pemberi memperoleh keuntungan baik materiil dan/atau moril, sementara dari pemberiannya itu, ada pihak lain yang dirugikan. ${ }^{7}$ Ada beberapa bentuk pengambilan harta milik orang

\footnotetext{
${ }^{4}$ Ahmad Sarwat, Seri Fiqih Kehidupan ( I6): Jinayat, (DU Publishing, Jakarta, 20 I I), I 0 I.

${ }^{5}$ Abddul Ghofur Anshori dan Yulkarnain Harahab, Hukum Islam: Dinamika dan Perkembangannya di Indonesia, (Kreasi Total Media: Yogyakarta, 2008), 240.

${ }^{6}$ Zainuddin Ali, Hukum Pidana Islam, (Sinar Grafika, Jakarta, 2007), 46.

${ }^{7}$ Zainuddin Ali, Hukum Islam: Pengantar IImu Hukum Islam di Indonesia (Sinar Grafika, Jakarta, $2010) 118$.
} 
lain yang diharamkan syariat dan mirip dengan tindak pencurian, namun tetap memiliki perbedaan, yaitu sebagai berikut:

a. Ikhtilas

Istilah ikhtilas (الإختاس) kalau diterjemahkan bermakna perampasan atau penjambretan. Ikhtilas didefinisikan sebagai: Mengambil harta orang lain dengan terangterangan dan sengaja, dengan teknik yang cepat dan melarikan diri. Dengan pengertian seperti di atas, maka perbedaan yang paling utama antara ikhtilas dengan sariqah adalah: ikhitlas itu dilakukan dengan terangterangan, sedangkan sariqah dilakukan dengan tersembunyi.

b. Khianat

Khianat (الخيانة) juga biasa disebut dengan istilah jahdulamanah (الأمانة جاحد) yaitu menodai amanah. Pelakunya disebut pengkhianat, yang didefinisikan sebagai: Orang yang diberi kepercayaan untuk menjaga pinjaman atau titipan, lalu dia mengambilnya dan berpura-pura hilang. Jadi tindakan pengkhiatan adalah pengambilan hak orang lain dimana pelakunya adalah orang yang diamanahi menjaga barang itu. Para koruptor masuk ke dalam tindak pengkhianatan, karena mereka memang orang yang sebelumnya dipercaya, diberi amanah serta dititipkan untuk menjaga harta. Tetapi dengan wewenang yang dimilikinya itu, harta itu malah diambilnya sendiri. Perbedaan hakiki antara khianat dan pencurian adalah bahwa pengkhianat ini adalah orang yang mengambil harta yang dititipkan kepadanya. Sedangkan pencuri adalah orang yang mengambil harta yang disimpan dengan aman, lalu dia menjebol pengamannya dan mengambil hartanya.

c. Ghashab

Ghashab (الغصب) didefinisikan sebagai: Pengambil-alihan hak orang lain dengan sewenang-wenang. Barangkali istilah yang agak dekat dengan makna ini dalam bahasa 
Indonesia adalah penjarahan, perampasan, perampokan atau pendudukan atas suatu harta dan sejenisnya.

d. Nabsy

Nabsy (النشش) adalah salah satu bentuk pencurian tetapi sangat spesifik, di masa lalu barangkali pernah terjadi kasusnya, meski kurang populer. Di zaman sekarang hampir tidak pernah terjadi. Pelaku tindakan ini disebut nabbasy, yang didefinisikan sebagai: Orang yang mencuri kain kafan mayat setelah dikuburkan dalam makamnya. Perbedaan nabsy dengan pencurian adalah bahwa harta yang diambil itu bukan harta yang disukai atau berharga. Selain itu, harta iu tidak dalam tempat penjagaan yang layak. Sedangkan dalam kasus pencurian, harta yang dicuri jelasjelas yang punya nilai dan harta itu disimpan di tempat yang layak sebagai tempat penyimpanan.

e. Nasyl

Istilah nasyl (النشل) sering diartikan sebagai pencopetan. Pelakunya disebut nasysyaal (النشال) dan didefinisikan oleh para ulama sebagai: Orang yang mencuri harta orangorang dalam keadaan jaga dengan kemampuan teknik tangan yang tersembunyi. Prinsipnya, pencopetan itu dilakukan dengan menggunakan kemahiran tangan, sehingga meski korbannya dalam keadaan sadar dan terjaga, namun secara tersembunyi hartnya telah lenyap. Sedangkan harta itu sebenarnya telah disimpan di tempat yang aman. ${ }^{8}$

Tindak pidana pencurian di dalam Kitab Undang-Undang Hukum Pidana diatur dalam bab tersendiri, yaitu pada bab XXII yang terdiri dari 6 buah pasal, yaitu Pasal 362, Pasal 363, Pasal 364, Pasal 365, Pasal 366, dan Pasal 367. R. Soesilo menyatakan bahwa menurut undang-undang, pencurian itu dibedakan atas lima macam pencurian, yaitu:

a. Pencurian biasa (Pasal $362 \mathrm{KUHP}$ );

${ }^{8}$ Ahmad Sarwat, Seri Fiqih Kehidupan..., $102-104$. 
b. Pencurian dengan pemberatan (Pasal 363 KUHP);

c. Pencurian dengan kekerasan (Pasal 365 KUHP);

d. Pencurian ringan (Pasal $364 \mathrm{KUHP}$ ); dan

e. Pencurian dalam kalangan keluarga (Pasal 367 KUHP). ${ }^{9}$

Pelaku pencurian (pencuri) pada masyarakat biasanya disebut dengan maling, sedangkan dalam bahasa belanda, pencurian dikenal dengan istilah diefstal. ${ }^{10}$ Menurut Tim Ikadin, dalam beberapa putusan yang ada, dalam perkara pencurian disebutkan unsur mengambil dalam delik pencurian tidaklah harus dipenuhi adanya perbuatan membawa pergi, tapi telah cukup jika barang yang menjadi objek dari perbuatan pelaku tindak pidana tersebut telah berada di bawah penguasaan sepenuhnya oleh pelaku. Hal yang dapat membedakan hukuman perbuatan pencurian menurut Tim Ikadin adalah alasan seorang yang mencuri, yaitu karena kebiasaan atau memang menjadi pekerjaannya, atau karena adanya kondisi tertentu yang terpaksa. ${ }_{11}$ Terkait dengan pemidanaan terhadap pelaku pencurian maka perlu diuraikan pendapat Achmad Ali yang menuliskan:

Ketika seorang hakim harus mengadili tiga orang pencuri ayam, dengan tiga kasus yang berbeda, yaitu korbannya berbeda dan waktu serta lokasi pencuriannya pun berbeda, maka dikatakan secara normatif, peraturan hukumnya persis sama, yaitu semuanya harus mengacu pada ketentuan Pasal 362 Kitab Undang-Undang Hukum Pidana. Namun secara sosiologis, aplikasi pasal tersebut tidak mungkin persis sama. Misalnya fakta yang terungkap di persidangan pengadilan:

a. Pencuri pertama, mencuri ayam dengan motif untuk menebus resep anaknya yang sedang sakit keras, yang jika resep itu tidak tertebus, anaknya kemungkinan besar akan meninggal dunia.

\footnotetext{
9 R. Soesilo, Pokok-pokok Hukum Pidana: Peraturan Umum dan Delik-delik Khusus, (Politea: Bogor, 1984), I 19-120.

${ }^{10}$ R. Subekti dan Tjitrosoedibio, Kamus Hukum, (Pradnya Paramita: Jakarta, 2008), 36.

II Tim Ikadin, Buku Pintar Hukum, (UII Press, Yogyakarta, 2007), 191.
} 
b. Pencuri kedua, mencuri ayam dengan motif untuk memperoleh uang bermalam minggu dengan pacarnya.

c. Pencuri ketiga, mencuri ayam dengan motif untuk membeli narkoba. ${ }^{12}$

Berdasarkan tiga jenis fakta yang dicontohkan Achmad Ali di atas, diketahui, selanjutnya dituliskan bahwa: Jelas seorang hakim yang baik, tak mungkin menjatuhkan vonis yang persis sama kepada tiga pencuri ayam itu. Kemungkinan sang hakim akan menjatuhkan maksimal ancaman pidana untuk pencurian terhadap pencuri ketiga yang mencuri karena mau membeli narkoba, dengan pidana sedang untuk pencuri yang mencuri untuk memperoleh uang membawa pacarnya bermalam Minggu; dan mungkin menjatuhkan pidana percobaan saja kepada pencuri pertama yang mencuri karena terpaksa demi menebus resep anaknya yang sakit keras. Inilah kegunaan praktis pertama mempelajari kajian empiris hukum, selain memahami kajian normatif dari hukum.

Tetap dengan ilustrasi pencurian di atas, sang hakim dalam membuat putusannya, maka faktor prapemahamannya juga sangat berperan (dapat bersifat sosiologis, psikologis, antropologis, moral, etika, religius, dan sebagainya). Misalnya, mengapa sang hakim menyatakan si pencuri itu terbukti melakukan tindak pidana pencurian, karena semua unsur tindak pidana dianggap telah terbukti, termasuk unsur "barang". Pertanyaannya, mengapa sang hakim menganggap "ayam" itu "barang"? Undang-undang sendiri tidak pernah menjelaskan secara perinci apa yang termasuk "barang". Dengan demikian, sang hakim memasukkan ayam sebagai "barang", tak lain sebagai hasil proses sosialisasinya sejak kecil, sehingga dia memahami bahwa ayam itu barang. Inilah kegunaan kedua dari kajian sosiologis, yang tak mungkin dipahami dengan sekadar kajian normatif. Pemahaman setiap

\footnotetext{
12 Achmad Ali, Menguak Teori Hukum (Legal Theory) \& Teori Peradilan (Judicialprudence): Termasuk Interpretasi Undang-undang (Legisprudence) Volume I Pemahaman Awal, (Prenada Media Group: Jakarta, 2009), I.
} 
orang, tanpa terkecuali, selalu dipengaruhi oleh prapengetahuan/ prapemahaman mereka. ${ }^{13}$

Pasal 362 KUHP berbunyi: "Barangsiapa mengambil barang sesuatu, yang seluruhnya atau sebagian kepunyaan orang lain, dengan maksud untuk dimiliki secara melawan hukum, diancam karena pencurian, dengan pidana penjara paling lama 5 tahun atau denda paling banyak enam puluh rupiah." 14 Pasal 362 mempunyai arti objektif dan subjektif ditinjau dari kata "wederrechtelijk" atau yang diterjemahkan ke dalam bahasa Indonesia, yaitu secara tidak sah. Dari arti objektif kata itu berarti melawan hukum atau bertentangan dengan hukum, dan dalam arti subjektif, yaitu tanpa sesuatu hak sendiri atau dengan melawan hak orang lain. ${ }^{15}$ Pasal 362 Kitab Undang-Undang Hukum Pidana menurut R. Soesilo adalah pencurian biasa. Elemen-elemennya sebagai berikut.

a. Perbuatan mengambil

b. Yang diambil harus sesuatu barang

c. Barang itu harus seluruhnya atau sebagian kepunyaan orang lain.

d. Pengambilan itu harus dilakukan dengan maksud untuk memiliki barang itu dengan melawan hukum (melawan hak). ${ }^{16}$

Elemen-elemen atau unsur-unsur dari Pasal 362 Kitab Undang-Undang Hukum Pidana oleh R. Soesilo diuraikan sebagai berikut.

a. Mengambil = mengambil untuk dikuasainya, maksudnya waktu pencuri mengambil barang itu, barang tersebut belum ada dalam kekuasaannya, apabila waktu memiliki itu barangnya sudah ada ditangannya, maka perbuatan ini bukan pencurian, tetapi penggelapan (pasal 372). Pengambilan

\footnotetext{
13 Ibid., I-2.

${ }_{14}$ Moeljatno, Kitab Undang-Undang Hukum Pidana, (Bumi Aksara: Jakarta, 2006), 128.

${ }^{15}$ R. Subekti dan Tjitrosoedibio, Kamus Hukum..., 36.

16 R. Soesilo, Kitab Undang-Undang Hukum Pidana (KUHP) serta Komentar-komentarnya Lengkap Pasal demi Pasal, (Politea: Bogor, 1991), 249.
}

$346 \quad \begin{aligned} & \text { al-Daulah } \\ & \text { Vol. 9. No. 2. Oktober } 2019\end{aligned}$ 
(pencurian) itu sudah dapat dikatakan selesai, apabila barang tersebut sudah pindah tempat. Bila orang baru memegang saja barang itu, dan belum berpindah tempat, maka orang itu belum dapat dikatakan mencuri, akan tetapi ia baru mencoba mencuri.

b. Sesuatu barang = segala sesuatu yang berwujud termasuk pula binatang (manusia tidak masuk), misalnya, uang, baju, kalung dan sebagainya. Dalam pengertian barang masuk pula daya listrik dan gas, meskipun tidak berwujud, akan tetapi dialirkan dikawat atau pipa. Barang ini tidak perlu mempunyai harga ekonomis. Oleh karena itu mengambil beberapa helai rambut wanita (untuk kenang-kenangan) tidak dengan izin wanita itu, masuk pencurian, meskipun dua helai rambut tidak ada harganya.

c. Barang itu seluruhnya atau sebagian kepunyaan orang lain. Sebagian kepunyaan orang lain misalnya: A bersama $B$ membeli sebuah sepeda, maka sepeda itu kepunyaan $\mathrm{A}$ dan $\mathrm{B}$, disimpan dirumah $\mathrm{A}$, kemudian dicuri oleh $B$, atau $A$ dan $B$ menerima barang warisan dari $C$, disimpan dirumah $A$, kemudian dicuri oleh $B$. Suatu barang yang bukan kepunyaan seseorang tidak menimbulkan pencurian, misalnya binatang liar yang hidup di alam, barang yang sudah dibuang oleh yang punya dan sebagainya.

d. Pengambilan itu harus dengan sengaja dan dengan maksud untuk dimilikinya. Orang karena keliru mengambil barang orang lain itu bukan pencurian. Seorang menemui barang di jalan kemudian diambilnya. Bila waktu mengambil itu sudah ada maksud untuk memiliki barang itu, masuk pencurian. Jika waktu mengambil itu pikiran terdakwa barang akan diserahkan pada polisi, akan tetapi serentak datang di rumah barang itu dimiliki untuk diri sendiri (tidak diserahkan kepada polisi), ia salah 
menggelapkan (pasal 372), karena waktu barang itu dimilikinya sudah berada ditangannya. ${ }^{17}$

\section{Perbandingan Hudud antara Ketentuan Hukum Islam dan Hukum Pidana Positif Indonesia}

Hirabah adalah salah satu bentuk perkara kriminal (jarimah), yang lebih dahsyat dari pembunuhan semata. Hirabah berasal dari kata harb (حرب ) yang artinya perang, yang merupakan lawan kata dari as-silmu (السبّلم حرب ) yang bermakna perdamaian. Hirabah adalah melakukan gabungan dari perampasan, penteroran, pembunuhan dan juga merusak di muka bumi. Hirabah merupakan serangkaian tindakan yang bersifat pisik dan mental. Sebab termasuk di dalamnya merampas harta dan membunuh. Juga termasuk di dalamnya menakut-nakuti orang yang lewat. Karena itu Allah SWT melebihkan ancaman hukuman bagi pelaku hirabah ini di atas ancaman hukuman pelaku pembunuhan atau pencurian. Ancaman ini berlaku bukan hanya bila tindak hirabah itu dilakukan kepada pemeluk agama Islam, tetapi juga bila dilakukan kepada pemeluk agama lainnya yang hidup di bawah pemerintahan Islam. Mereka adalah kafir zimmi yang berada dalam ikatan mu'ahadah dengan pemerintah Islam yang berdaulat. ${ }^{18}$ Untuk bisa dikategorikan sebagai pelaku tindak hirabah secara hukum, maka haruslah didapat kriteria:

a. Memiliki kekuatan, syaukah dan man'ah

Kekuatan dan kemampuan untuk memaksa ini akan membedakan mereka dengan pencuri biasa. Sebab seorang pencuri dalam pandangan hukum Islam adalah orang yang mengambil harta orang lain dalam tempat penyimpanannya dengan diam-diam, bukan dengan kekuatan atau pemaksaan atau kekerasan. Demikian juga hal tersebut ditandai dengan membawa senjata yang mematikan seperti pedang, golok, arit dan

17 lbid., 250.

${ }^{18}$ Ahmad Sarwat, Seri Fiqih Kehidupan..., I83- 184.

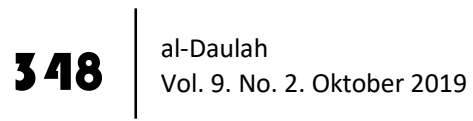


sejenisnya yang dengan itu bisa digunakan untuk membunuh atau mencederai korbannya.

b. Dilakukan di wilayah Darul Islam

Kejadiannya haruslah terjadi di wilayah hukum Islam, meski bukan harus di dalam kota/peradaban. Bahkan Abu Hanifah mengatakan bahwa kejadiannya itu haruslah di luar kota, sebab bila di dalam kota, masih mungkin untuk meminta pertolongan dari umat Islam lainnya. Namun jumhur ulama tidak mensyaratkan harus di dalam atau di luar kota. Sebab di masa kini, kejahatan justru banyak terjadi di dalam kota besar, bahkan di wilayah pemukiman penduduk.

c. Merampas dengan Paksa

Sebab bila dilakukan dengan diam-diam tidak disebut sebagai perampasan, namun pencurian. Dan bila kasusnya pengambilan dengan diam-diam yang berarti pencurian, maka hukumannya bukan dipotong tangan dan kaki secara bersilang, namun cukup dipotong tangannya saja. Karena demikianlah hukuman pencuri. ${ }^{19}$

Allah SWT telah menyebutkan bentuk-bentuk hukuman buat para pelaku tindak kriminal hirabah. Yaitu dibunuh, dibunuh dengan cara disalib, dipotong tangan dan kaki dengan bersilangan dan diasingkan atau dibuang dari tempatnya. Uraian bentukbentuk hukuman tersebut adalah sebagai berikut.

a. Dibunuh

Pelaku hirabah dibunuh dengan had tanpa disalib, bila mereka hanya penghilangkan nyawa manusia tanpa merampas. Istimewanya, hukuman bunuh ini sama sekali tidak bisa dibatalkan meski ada pernyataan maaf dari pihak korban. Tidak seperti kasus pembunuhan biasa dalam hukum hudud yang masih dimungkinkan dibatalkannya hukuman bila pihak korban atau

${ }^{19}$ lbid., $188-189$. 
keluarganya memberikan permaafan. Sehingga bisa dengan membayar diyat saja. Khusus dalam kasus hirabah, permaafan dari pihak korban atau keluarganya sama sekali tidak bisa membatalkan hukuman mati kepada pelaku tindak hirabah.

b. Dibunuh dengan Disalib

Dilakukan bila membunuh sekaligus merampas harta korban. Penyaliban sendiri bentuknya adalah mengikatkan pelaku pada kayu saling yang ditegakkan dengan kaki di bawah dan tangan di atas. Dalam masalah waktu penyaliban ini, ada perbedaan di kalangan para ulama: Dalam mazhab dalam mazhab As-Syafi'iyah dan AlHanabilah, penyaliban dilakukan setelah dibunuh terlebih dahulu. Sebab mereka berpedoman bahwa penyiksaan itu dilarang, demikian juga menyalib hewan dilarang oleh Rasulullah SAW. Sebaliknya, Al-Hanafiyah dan AlMalikiyah yang shahih adalah dengan mengikatnya demikian pada kayu salib selama tiga hari hidup-hidup barulah dibunuh. Sebab penyalib setelah orangnya mati tidak ada gunanya, sebab hukuman itu hanya diberlakukan pada orang hidup.

c. Potong tangan dan kaki secara bersilangan Hukuman ini untuk mereka yang hanya merampas harta dan tidak sampai membunuh korbannya. Maksudnya bersilangan adalah memotong tangan kanan dan kaki kiri pelakunya.

d. Dibuang

Hukuman ini bila hanya pelakunya melakukan teror semata atau menakuti korbannya dengan mengancam. Namun pada hakikatnya tidak sampai membunuh ataupun merampas harta. Al-Hanafiyah memaknainya dengan pemenjaraan. Sedangkan membuangnya ke ngeri asing merupakan hal yang membahayakanbiak untuk dirinya ataupun untuk negeri tempat dibuangnya. Bahkan malah bisa membuatnya lari dan membelot ke darul harb. 
Sedangkan Al-Malikiyah mengatakan bahwa yang membuang pelaku adalah menempatkannya ke tempat yang jauh dari tempat tinggalnya dengan jarak minimal adalah jarak dibolekhannya mengqashar shalat. Jaraknya adalah $89 \mathrm{~km}$. Di sanalah pelakunya dipenjarakan. ${ }^{20}$

Di dalam hukum Islam ada dua pencurian: pencurian yang mewajibkan jatuhnya hukum hudud, pencurian yang mewajibkan jatuhnya hukuman takzir. Pencurian yang mewajibkan jatuhnya hukuman hudud ada dua macam: pencurian kecil (sariqah sugra) dan pencurian besar (sariqah kubra). Pencurian yang hukumannya takzir: pertama, setiap pencurian kecil atau besar yang seharusnya dijatuhi hukuman hudud, tetapi syarat-syaratnya tidak terpenuhi atau gugur karena ada syubhat. Misalnya, mengambil harta anak sendiri atau harta milik bersama. Kedua, mengambil harta orang lain dengan terang-terangan atau sepengetahuan korban, tanpa kekerasan atau kerelaan korban. Pencurian kecil adalah mengambil harta orang lain dengan cara sembunyi-sembunyi, sedangkan pencurian besar adalah mengambil harta orang lain dengan cara memaksa. Pencurian besar ini disebut hirabah (merampok atau melakukan gangguan keamanan). ${ }^{21}$

Menurut Abd al Qadir Audah dan al Sayid Sabiq, terminologis pencurian besar adalah mengambil harta orang lain dengan kekerasan dan ini disebut juga dengan merampok atau begal. Walaupun tindak pidana hirabah dinamakan pencurian besar (sariqah kubra), ia tidak benar-benar mirip dengan pencurian. Pencurian adalah pengambilan harta secara sembunyi-sembunyi, sedangkan hirabah adalah keluar (rumah) untuk mengambil harta secara paksa. ${ }^{22}$

Pencurian dengan kekerasan menurut Pasal 365 Kitab Undang-Undang Hukum Pidana adalah sebagai berikut:

\footnotetext{
20 |bid,. |90-|9|.

21 Thaufik Rachman, Kategorisasi Tindak Pidana Pencurian dalam Hukum Islam, Skripsi, (Jurusan Jinayah Siyasah, Fakultas Syari'ah, Institut Agama Islam Negeri Walisongo: Semarang, 20I I), 4-5.

22 Ibid., 25.
} 
a. Pasal 365 ayat (1) KUHP: “Diancam dengan pidana penjara paling lama sembilan tahun pencurian yang didahului, disertai atau diikuti dengan kekerasan atau ancaman kekerasan, terhadap orang dengan maksud untuk mempersiapkan atau mempermudah pencurian, atau dalam hal tertangkap tangan, untuk memungkinkan melarikan diri sendiri atau peserta lainnya, atau untuk tetap menguasai barang yang dicuri."

b. Pasal 365 ayat (2) KUHP: "Diancam dengan pidana penjara paling lama dua belas tahun: 1. jika perbuatan dilakukan pada waktu malam dalam sebuah rumah atau pekarangan tertutup yang ada rumahnya, di berjalan; 2. jika perbuatan dilakukan oleh dua orang atau lebih dengan bersekutu; 3. jika masuk ke tempat melakukan kejahatan dengan merusak atau memanjat atau dengan memakai anak kunci palsu, periniah palsu atau pakaian jabatan palsu. 4. jika perbuatan mengakibatkan luka-luka berat."

c. Pasal 365 ayat (3) KUHP: "Jika perbuatan mengakibatkan kematian maka diancam dengan pidana penjara paling lama lima belas tahun."

d. Pasal 365 ayat (4) KUHP: "Diancam dengan pidana mati atau pidana penjara seumur hidup atau selama waktu tertentu paling lama dua puluh tahun, jika perbuatan mengakibatkan luka berat atau kematian dan dilakukan oleh dua orang atau lebih dengan bersekutu, disertai pula oleh salah satu hal yang diterangkan dalam no. 1 dan 3."

Penodongan adalah merampas atau mengambil harta milik orang lain dengan cara memaksa korbannya. Umumnya kata penodongan lebih lazim dipakai terhadap tindak pidana yang dilakukan di luar rumah. Jika perbuatan yang sama dilakukan oleh pelaku di dalam rumah atau gedung disebut perampokan. Dalam 
hukum Islam perilaku kriminal penodongan atau perampokan disebut muharabah..$^{23}$

Potong tangan, rajam, cambuk, hukum gantung, hukum mati dengan disalib, penggal kepala, barangkali semua itulah yang terlintas di benak di kepala setiap orang tatkala mendengar istilah hukum Islam, jinayat atau hudud. Memang tidak bisa dipungkiri bahwa semua itu bagian dari hukum jinayat dalam syariat Islam. Yang perlu diluruskan adalah bahwa hukum-hukum itu tidak serta merta diterapkan kepada sembarang orang. Tidak setiap orang yang diduga menjadi pencuri lantas boleh dipukuli ramairamai oleh masa yang bringas, sambil terakhir dipotong tangannya. Tidak setiap ada pasangan lawan jenis berduaan bukan mahram lantas boleh ditelanjangi dan diarak keliling kampung, lalu dicambuk atau dilempari batu hingga mati. Tidak setiap orang yang minum khamar lantas menjadi harus dipukuli dengan rotan atau cemeti sampai memar dan berdarah. Tidak setiap orang yang membunuh orang lain, boleh lantas dihukum juga dengan vonis mati. Tidak semua mata harus dibayar dengan mata, tidak semua telinga harus dibayar dengan telinga, tidak semua hidung harus dibayar dengan hidung, tidak semua luka harus dibayar dengan luka karena kalau mau diteliti dengan lebih jernih dan tenang, ada sejumlah prosedur dan segudang persyaratan yang harus terpenuhi agar hukum-hukum itu boleh dilaksanakan. ${ }^{24}$

Berdasarkan rumusan masalah dalam makalah ini, kesimpulan yang diperoleh adalah sebagai berikut:

Perbandingan hudud antara ketentuan hukum Islam dan hukum pidana positif terhadap pencurian atau perbuatan mengambil harta orang lain secara sembunyi-sembunyi di dalam tempat simpanan hak orang lain tersebut adalah dalam hukum Islam, pencurian, yaitu mengambil harta milik orang lain dengan cara sembunyi dari tempat simpanan dengan maksud untuk dimiliki. Ancaman hukuman pencurian adalah potong tangan, namun harus memenuhi syarat-syarat tertentu yaitu: pencurinya

${ }^{23}$ Zainuddin Ali, Hukum Islam: Pengantar IImu Hukum Islam..., I2I.

${ }^{24}$ Ahmad Sarwat, Seri Fiqih Kehidupan..., 21-22. 
harus dewasa, berakal sehat, dan tidak terpaksa, harta itu milik orang lain, pencuri mengambil harta dari tempat simpanan yang semestinya, sesuai dengan macam harta yang dicuri, harta yang dicuri memenuhi minimal 1,62 gram, dan pencurian tidak terjadi karena daya paksa, misalnya orang yang kelaparan mencuri untuk menyelamatkan jiwanya.

Dalam hukum pidana positif pencurian itu harus memenuhi elemen atau unsur-unsur, yaitu perbuatan mengambil, yang diambil harus sesuatu barang, barang itu harus seluruhnya atau sebagian kepunyaan orang lain, pengambilan itu harus dilakukan dengan maksud untuk memiliki barang itu dengan melawan hukum (melawan hak). Dalam hukum pidana positif, tidak diberikan suatu "pembenaran" untuk melakukan pencurian dan ancaman bagi pencuri tidak mencederai fisiknya secara langsung karena menurut Pasal 362 KUHP, ancamannya adalah pidana penjara paling lama 5 tahun atau denda paling banyak enam puluh rupiah. Ada beberapa bentuk pengambilan harta milik orang lain yang diharamkan syariat dan mirip dengan tindak pencurian, namun tetap memiliki perbedaan, yaitu sebagai berikut: ikhtilas yang bermakna perampasan atau penjambretan. Khianat, pelakunya disebut pengkhianat. Para koruptor masuk ke dalam tindak pengkhianatan. Ghashab atau penjarahan, perampasan, perampokan atau pendudukan atas suatu harta dan sejenisnya, Nabsy, yaitu mencuri kain kafan mayat setelah dikuburkan dalam makamnya. Nasyl atau pencopetan.

Tindak pidana pencurian di dalam Kitab Undang-Undang Hukum Pidana diatur dalam bab tersendiri, yaitu pada bab XXII yang terdiri dari 6 buah pasal, yaitu Pasal 362, Pasal 363, Pasal 364, Pasal 365, Pasal 366, dan Pasal 367. Pencurian itu dibedakan atas lima macam pencurian, yaitu: Pencurian biasa (Pasal 362 KUHP); Pencurian dengan pemberatan (Pasal 363 KUHP); Pencurian dengan kekerasan (Pasal 365 KUHP); Pencurian ringan (Pasal 364 KUHP); dan Pencurian dalam kalangan keluarga (Pasal 367 KUHP). 
Perbandingan hudud antara ketentuan hukum Islam dan hukum pidana positif terhadap penodongan atau perampokan adalah hirabah yang bermakna melakukan gabungan dari perampasan, penteroran, pembunuhan dan juga merusak di muka bumi merupakan serangkaian tindakan yang bersifat pisik dan mental. Sebab termasuk di dalamnya merampas harta dan membunuh. Juga termasuk di dalamnya menakut-nakuti orang yang lewat. Karena itu Allah SWT melebihkan ancaman hukuman bagi pelaku hirabah ini di atas ancaman hukuman pelaku pembunuhan atau pencurian. Ancaman ini berlaku bukan hanya bila tindak hirabah itu dilakukan kepada pemeluk agama Islam, tetapi juga bila dilakukan kepada pemeluk agama lainnya yang hidup di bawah pemerintahan Islam.

Allah SWT telah menyebutkan bentuk-bentuk hukuman buat para pelaku tindak kriminal hirabah, yaitu dibunuh (bila mereka hanya penghilangkan nyawa manusia tanpa merampas), dibunuh dengan Disalib (bila membunuh sekaligus merampas harta korban), potong tangan dan kaki secara bersilangan (mereka yang hanya merampas harta dan tidak sampai membunuh korbannya), dibuang (bila hanya pelakunya melakukan teror semata atau menakuti korbannya dengan mengancam).

Ancaman hukuman untuk pencurian dengan kekerasan menurut Pasal 365 Kitab Undang-Undang Hukum Pidana adalah: Pasal 365 ayat (1) KUHP (pidana penjara paling lama sembilan tahun untuk pencurian yang didahului, disertai atau diikuti dengan kekerasan atau ancaman kekerasan, terhadap orang dengan maksud untuk mempersiapkan atau mempermudah pencurian, atau dalam hal tertangkap tangan, untuk memungkinkan melarikan diri sendiri atau peserta lainnya, atau untuk tetap menguasai barang yang dicuri), Pasal 365 ayat (2) KUHP (pidana penjara paling lama dua belas tahun: 1. jika perbuatan dilakukan pada waktu malam dalam sebuah rumah atau pekarangan tertutup yang ada rumahnya, di berjalan; 2. jika perbuatan dilakukan oleh dua orang atau lebih dengan bersekutu; 3. jika masuk ke tempat melakukan kejahatan dengan merusak 
atau memanjat atau dengan memakai anak kunci palsu, periniah palsu atau pakaian jabatan palsu. 4. jika perbuatan mengakibatkan luka-luka berat), Pasal 365 ayat (3) KUHP (pidana penjara paling lama lima belas tahun jika perbuatan mengakibatkan kematian). Pasal 365 ayat (4) KUHP (pidana mati atau pidana penjara seumur hidup atau selama waktu tertentu paling lama dua puluh tahun, jika perbuatan mengakibatkan luka berat atau kematian dan dilakukan oleh dua orang atau lebih dengan bersekutu).

\section{Penutup}

Perbandingan hudud antara ketentuan hukum Islam dan hukum pidana positif terhadap pencurian atau perbuatan mengambil harta orang lain secara sembunyi-sembunyi di dalam tempat simpanan hak orang lain tersebut adalah dalam hukum Islam, pencurian, yaitu mengambil harta milik orang lain dengan cara sembunyi dari tempat simpanan dengan maksud untuk dimiliki. Ancaman hukuman pencurian adalah potong tangan, namun harus memenuhi syarat-syarat tertentu yaitu: pencurinya harus dewasa, berakal sehat, dan tidak terpaksa, harta itu milik orang lain, pencuri mengambil harta dari tempat simpanan yang semestinya, sesuai dengan macam harta yang dicuri, harta yang dicuri memenuhi minimal 1,62 gram, dan pencurian tidak terjadi karena daya paksa, misalnya orang yang kelaparan mencuri untuk menyelamatkan jiwanya.

Dalam hukum pidana positif pencurian itu harus memenuhi elemen atau unsur-unsur, yaitu perbuatan mengambil, yang diambil harus sesuatu barang, barang itu harus seluruhnya atau sebagian kepunyaan orang lain, pengambilan itu harus dilakukan dengan maksud untuk memiliki barang itu dengan melawan hukum (melawan hak). Dalam hukum pidana positif, tidak diberikan suatu "pembenaran" untuk melakukan pencurian dan ancaman bagi pencuri tidak mencederai fisiknya secara langsung karena menurut Pasal 362 KUHP, ancamannya adalah pidana penjara paling lama 5 tahun atau denda paling banyak enam puluh rupiah. Ada beberapa bentuk pengambilan harta 
milik orang lain yang diharamkan syariat dan mirip dengan tindak pencurian, namun tetap memiliki perbedaan, yaitu sebagai berikut: ikhtilas yang bermakna perampasan atau penjambretan. Khianat, pelakunya disebut pengkhianat. Para koruptor masuk ke dalam tindak pengkhianatan. Ghashab atau penjarahan, perampasan, perampokan atau pendudukan atas suatu harta dan sejenisnya, Nabsy, yaitu mencuri kain kafan mayat setelah dikuburkan dalam makamnya. Nasyl atau pencopetan.

Tindak pidana pencurian di dalam Kitab Undang-Undang Hukum Pidana diatur dalam bab tersendiri, yaitu pada bab XXII yang terdiri dari 6 buah pasal, yaitu Pasal 362, Pasal 363, Pasal 364, Pasal 365, Pasal 366, dan Pasal 367. Pencurian itu dibedakan atas lima macam pencurian, yaitu: Pencurian biasa (Pasal 362 KUHP); Pencurian dengan pemberatan (Pasal 363 KUHP); Pencurian dengan kekerasan (Pasal 365 KUHP); Pencurian ringan (Pasal 364 KUHP); dan Pencurian dalam kalangan keluarga (Pasal 367 KUHP).

Perbandingan hudud antara ketentuan hukum Islam dan hukum pidana positif terhadap penodongan atau perampokan adalah hirabah yang bermakna melakukan gabungan dari perampasan, penteroran, pembunuhan dan juga merusak di muka bumi merupakan serangkaian tindakan yang bersifat pisik dan mental. Sebab termasuk di dalamnya merampas harta dan membunuh. Juga termasuk di dalamnya menakut-nakuti orang yang lewat. Karena itu Allah SWT melebihkan ancaman hukuman bagi pelaku hirabah ini di atas ancaman hukuman pelaku pembunuhan atau pencurian. Ancaman ini berlaku bukan hanya bila tindak hirabah itu dilakukan kepada pemeluk agama Islam, tetapi juga bila dilakukan kepada pemeluk agama lainnya yang hidup di bawah pemerintahan Islam. Allah SWT telah menyebutkan bentuk-bentuk hukuman buat para pelaku tindak kriminal hirabah, yaitu dibunuh (bila mereka hanya penghilangkan nyawa manusia tanpa merampas), dibunuh dengan Disalib (bila membunuh sekaligus merampas harta korban), potong tangan dan kaki secara bersilangan (mereka yang hanya merampas harta dan 
tidak sampai membunuh korbannya), dibuang (bila hanya pelakunya melakukan teror semata atau menakuti korbannya dengan mengancam).

Ancaman hukuman untuk pencurian dengan kekerasan menurut Pasal 365 Kitab Undang-Undang Hukum Pidana adalah: Pasal 365 ayat (1) KUHP (pidana penjara paling lama sembilan tahun untuk pencurian yang didahului, disertai atau diikuti dengan kekerasan atau ancaman kekerasan, terhadap orang dengan maksud untuk mempersiapkan atau mempermudah pencurian, atau dalam hal tertangkap tangan, untuk memungkinkan melarikan diri sendiri atau peserta lainnya, atau untuk tetap menguasai barang yang dicuri), Pasal 365 ayat (2) KUHP (pidana penjara paling lama dua belas tahun: 1. jika perbuatan dilakukan pada waktu malam dalam sebuah rumah atau pekarangan tertutup yang ada rumahnya, di berjalan; 2. jika perbuatan dilakukan oleh dua orang atau lebih dengan bersekutu; 3. jika masuk ke tempat melakukan kejahatan dengan merusak atau memanjat atau dengan memakai anak kunci palsu, periniah palsu atau pakaian jabatan palsu. 4. jika perbuatan mengakibatkan luka-luka berat), Pasal 365 ayat (3) KUHP (pidana penjara paling lama lima belas tahun jika perbuatan mengakibatkan kematian). Pasal 365 ayat (4) KUHP (pidana mati atau pidana penjara seumur hidup atau selama waktu tertentu paling lama dua puluh tahun, jika perbuatan mengakibatkan luka berat atau kematian dan dilakukan oleh dua orang atau lebih dengan bersekutu).

\section{Daftar Pustaka}

Abddul Ghofur Anshori dan Yulkarnain Harahab, Hukum Islam: Dinamika dan Perkembangannya di Indonesia, Kreasi Total Media, Yogyakarta, 2008.

Abdurrahman Wahid, Islamku, Islam Anda, Islam Kita: Agama Masyarakat Negara Demokrasi, Wahid Institute, Jakarta, 2006.

$358 \mid$\begin{tabular}{l|l} 
al-Daulah \\
Vol. 9. No. 2. Oktober 2019
\end{tabular} 
Achmad Ali, Menguak Teori Hukum (Legal Theory) \& Teori Peradilan (Judicialprudence): Termasuk Interpretasi Undang-undang (Legisprudence) Volume I Pemahaman Awal, Prenada Media Group, Jakarta, 2009.

Ahmad Sarwat, Seri Fiqih Kehidupan (16): Jinayat, DU Publishing, Jakarta, 2011.

Moeljatno, Kitab Undang-Undang Hukum Pidana, Bumi Aksara, Jakarta, 2006.

R. Soesilo, Kitab Undang-Undang Hukum Pidana (KUHP) serta Komentar-komentarnya Lengkap Pasal demi Pasal, Politea, Bogor, 1991.

R. Soesilo, Pokok-pokok Hukum Pidana: Peraturan Umum dan Delik-delik Khusus, Politea, Bogor, 1984.

R. Subekti dan Tjitrosoedibio, Kamus Hukum, Pradnya Paramita, Jakarta, 2008.

Sulaiman Rasjid, Fiqh Islam, Sinar Baru Algensindo, Bandung, 1994.

Thaufik Rachman, Kategorisasi Tindak Pidana Pencurian dalam Hukum Islam, Skripsi, Jurusan Jinayah Siyasah, Fakultas Syari'ah, Institut Agama Islam Negeri Walisongo, Semarang, 2011.

Tim Ikadin, Buku Pintar Hukum, UII Press, Yogyakarta, 2007.

Tim Tsalisah, Ensiklopedi Hukum Pidana Islam, PT Kharisma Ilmu. Diterjemahkan dari buku At-Tasyri' al-Jina'i allslamiy Muqaranan bil Qanunil Wad'iy.

Zainuddin Ali, Hukum Islam: Pengantar Ilmu Hukum Islam di Indonesia, Sinar Grafika, Jakarta, 2010

Zainuddin Ali, Hukum Pidana Islam, Sinar Grafika, Jakarta, 2007. 